\title{
Behavior of HPC with Fly Ash after Elevated Temperature
}

\author{
Huai-Shuai Shang ${ }^{1,2}$ and Ting-Hua $\mathrm{Yi}^{3}$ \\ ${ }^{1}$ School of Civil Engineering, Qingdao Technological University, Qingdao 266033, China \\ ${ }^{2}$ State Key Laboratory of Structural Analysis for Industrial Equipment, Dalian University of Technology, Dalian 116024, China \\ ${ }^{3}$ Faculty of Infrastructure Engineering, Dalian University of Technology, Dalian 116023, China
}

Correspondence should be addressed to Huai-Shuai Shang; shanghuaishuai@yahoo.com.cn

Received 3 January 2013; Accepted 10 March 2013

Academic Editor: Dimitar Dontchev

Copyright (C) 2013 H.-S. Shang and T.-H. Yi. This is an open access article distributed under the Creative Commons Attribution License, which permits unrestricted use, distribution, and reproduction in any medium, provided the original work is properly cited.

For use in fire resistance calculations, the relevant thermal properties of high-performance concrete (HPC) with fly ash were determined through an experimental study. These properties included compressive strength, cubic compressive strength, cleavage strength, flexural strength, and the ultrasonic velocity at various temperatures $\left(20,100,200,300,400\right.$ and $\left.500^{\circ} \mathrm{C}\right)$ for highperformance concrete. The effect of temperature on compressive strength, cubic compressive strength, cleavage strength, flexural strength, and the ultrasonic velocity of the high-performance concrete with fly ash was discussed according to the experimental results. The change of surface characteristics with the temperature was observed. It can serve as a reference for the maintenance, design, and the life prediction of high-performance concrete engineering, such as high-rise building, subjected to elevated temperatures.

\section{Introduction}

High-performance concrete (HPC) [1-5] is a complex system of materials that perform most effectively when placed in severely aggressive environments. It has found widespread usage in construction application including bridges, tunnels and high-rise building. Concrete in normal conditions is a versatile, resistant, and durable construction material. However under several physical and chemical processes as well as certain environmental conditions, it may deteriorate in a short period of time. As the use of high-performance concrete becomes common, the risk of exposing it to elevated temperatures also increases. The behavior of highperformance concrete under elevated temperatures differs from that of plain concrete. To be able to predict the response of structures employing high-performance concrete during and after exposure to high temperature, it is essential that the strength properties of high-performance concrete subjected to high temperatures should be clearly understood.

Fly ash (FA) is a byproduct of thermal power stations [6]. It is estimated that approximately 600 million tons of FA are available worldwide now, but at present, the current worldwide utilization rate of FA in concrete is about 10\% [7]. FA is one of the most common concrete ingredients due to their pozzolanic properties $[7,8]$. In the past two decades, considerable attention has been given to the use of FA as a partial replacement for cement in the production of highperformance concrete.

Kim et al. [9] studied the effect of elevated temperatures ranging from $20^{\circ} \mathrm{C}$ to $700^{\circ} \mathrm{C}$ on the mechanical properties of high-strength concrete of 40,60 , and $80 \mathrm{MPa}$ grades. Poon et al. [10] investigated the effects of elevated temperatures on the compressive strength of fiber reinforced high-performance concrete. The results showed that, after exposure to 600 and $800^{\circ} \mathrm{C}$, the concrete mixes retained, respectively, $45 \%$ and $23 \%$ of their compressive strength, on average. Khaliq and Kodur [11] present the effect of temperature on thermal and mechanical properties of high-performance selfconsolidating concrete. In particular, there is a great risk that HPC spalls at elevated temperature compared with plain concrete $[12,13]$. Due to the poor fire resistance of HPC $[14,15]$, it should be recommended that the use of HPC should be limited in some cases unless future research is carried out to study and solve this problem. Thus, the investigation on 
TABLE 1: Mix proportions and major parameters of concrete.

\begin{tabular}{lccccccc}
\hline Strength level & $\begin{array}{c}\text { Cement } \\
\left(\mathrm{kg} / \mathrm{m}^{3}\right)\end{array}$ & $\begin{array}{c}\text { Sand } \\
\left(\mathrm{kg} / \mathrm{m}^{3}\right)\end{array}$ & $\begin{array}{c}\text { Coarse aggregate } \\
\left(\mathrm{kg} / \mathrm{m}^{3}\right)\end{array}$ & $\begin{array}{c}\text { Water } \\
\left(\mathrm{kg} / \mathrm{m}^{3}\right)\end{array}$ & $\begin{array}{c}\text { Fly ash } \\
\left(\mathrm{kg} / \mathrm{m}^{3}\right)\end{array}$ & $\begin{array}{c}\text { Water-reducing agent } \\
\left(\mathrm{kg} / \mathrm{m}^{3}\right)\end{array}$ & $\begin{array}{c}\text { Slump } \\
(\mathrm{cm})\end{array}$ \\
\hline C60 & 470 & 616 & 1095 & 175 & 94.5 & 6.77 & 24 \\
C50 & 434 & 640 & 1080 & 185 & 91.0 & 5.81 & 25 \\
\hline
\end{tabular}

performance of HPC subjected to elevated temperature is of great significance. This paper presents an experimental study of high-performance concrete with characteristic compressive strength of about $50 \mathrm{MPa}$ and $60 \mathrm{MPa}$ after $20^{\circ} \mathrm{C}, 200^{\circ} \mathrm{C}$, $300^{\circ} \mathrm{C}, 400^{\circ} \mathrm{C}$, and $500^{\circ} \mathrm{C}$ according to the $\mathrm{GB} / \mathrm{T} 50081-$ 2002 (standard for test method of mechanical properties on ordinary concrete) [16]. The compressive strength, cubic compressive strength, cleavage strength, flexural strength, and the ultrasonic velocity of HPC with fly ash were measured. The objective of this study is to increase the insight of the mechanical behavior of high-performance concrete with FA after exposure to elevated temperatures.

\section{Experimental Procedures}

2.1. Materials and Mix Proportions. To produce such a better quality of concrete, chemical and mineral admixtures such as fly ash, slag cement, and water reducers are commonly used in the field construction to increase the concrete strength. In this experimental study, two high performance concrete mixes have been studied, one high-performance concrete with a characteristic compressive strength of about $50 \mathrm{MPa}$, denominated C50, and another high-performance concrete, designed to achieve a compressive strength of about $60 \mathrm{MPa}$, denominated C60. In this experimental study, samples were made in a variety of trial concrete mix proportions and tested to determine the proportion which provided the required strength. Local materials were utilized. A Chinese standard (GB175-99) [17] 525 Portland cement (which has standard compressive strength of $52.5 \mathrm{MPa}$ at the age of 28 days) was used. Natural river sand with fineness modulus of 2.6 was used. Coarse aggregate was a crushed stone with diameter from $5 \mathrm{~mm}$ to $20 \mathrm{~mm}$. FA was applied to the mixture to the proportion of $20 \%(\mathrm{C} 50)$ and $21 \%$ (C60) of cement weight. Due to low water-cement ratios of the concrete mixtures, a water-reducing agent was employed. The mixture proportions and the major parameters for the two batches are listed in Table 1.

2.2. Samples and Testing Programs. In this study, all mixes were elaborated using a $0.25 \mathrm{~m}^{3}$ horizontal forced action mixer. The mixing procedure was as follows: first the coarse aggregate, then fine aggregate, and the cement were loaded with the FA. These components were mixed for about 1 minute and after it the water with water-reducing agent was added in one minute and the mixing continued for another 3 minutes and the process finished.

Concrete prisms with size of $100 \mathrm{~mm} \times 100 \mathrm{~mm} \times 100 \mathrm{~mm}$ to determine the compressive strength (in order to eliminate the restraint on the loading surfaces, the friction-reducing pads were placed between the platens and the specimens for all tests. The pads consist of three plastic membranes with three layers of butter between them [18]), cubic compressive strength, cleavage strength, and the ultrasonic velocity and $100 \mathrm{~mm} \times 100 \mathrm{~mm} \times 400 \mathrm{~mm}$ to determine the flexural strength were casted in steel molds. During casting, compaction was achieved by placing the molds on a vibrating table and vibrating it at a frequency of $40 \mathrm{HZ}$ for one second. All cast specimens were compacted through external vibration and demoulded $24 \mathrm{~h}$ later. Thereafter, all the specimens were cured in a moisture room with a condition of $20 \pm$ $3^{\circ} \mathrm{C}$ and $95 \% \mathrm{RH}$ for 27 days. At 28 days, the specimens were transported to the normal environment. At 120 days, the specimens were ground and prepared for testing. The two sides of specimen were ground to ensure that the specimen had flat edges and right angle corners. The final ground surface finish was within $\pm 0.01 \mathrm{~mm}$.

The tests of high temperatures were performed in the high temperatures testing apparatus in State Key Laboratory of Coastal and Offshore Engineering, Dalian University of Technology. The high temperatures testing apparatus was a box-type electric furnace, as shown in Figure 1. The $100 \mathrm{~mm}$ cubic specimens were elevated to the peak temperatures of $200^{\circ} \mathrm{C}, 300^{\circ} \mathrm{C}, 400^{\circ} \mathrm{C}$, and $500^{\circ} \mathrm{C}$ at a heating rate of $10^{\circ} \mathrm{C} / \mathrm{min}$, respectively. Then $6 \mathrm{~h}$ was maintained after the peak temperature was reached. The cooling time in electric furnace was about $24 \mathrm{~h}$, and then the specimens were taken out and cooled naturally to room temperature.

The compression testing machine used for this experiment was a machine with a maximum capacity of $100 \mathrm{KN}$, as shown in Figure 2. Compressive testing of the test specimens was done in accordance with (standard for test method of mechanical properties on ordinary concrete) GB/T 500812002 [16]. The maximum loading force was always applied to the surfaces that were perpendicular to the cast surfaces. The testing of the specimens can be carried out in stresscontrolled mode, and all specimens were tested at a loading speed of 20.0 MPa per minute.

\section{Results and Discussions}

3.1. Failure Modes. Figures 3(a) and 3(b) show the failure modes of HPC under uniaxial compression with and without friction-reducing pads, respectively. The column-type fragments were observed for HPC under uniaxial compression with friction-reducing pads. The tensile strain will be caused in the direction of free surface because of the action of compressive load and the crack forms when the strain was larger than the ultimate tensile strain of the specimen. It was noticed that the cracks on the loaded surface have a random direction because of the influence of coarse aggregates. 


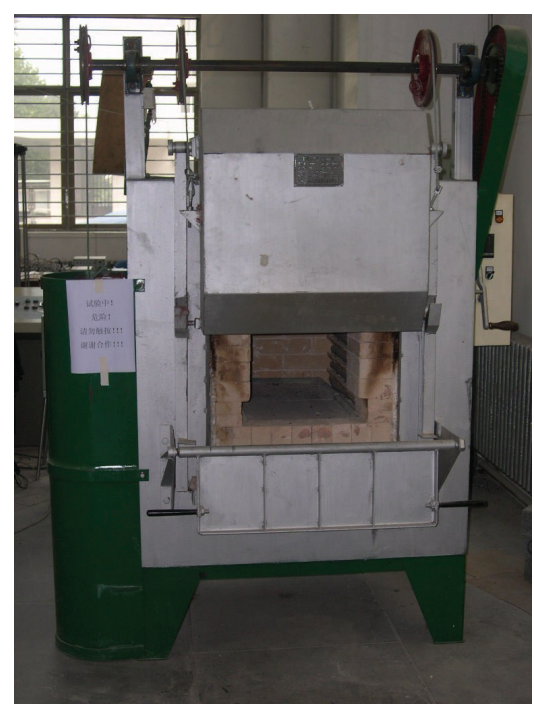

FIGURE 1: Box-type electric furnace.

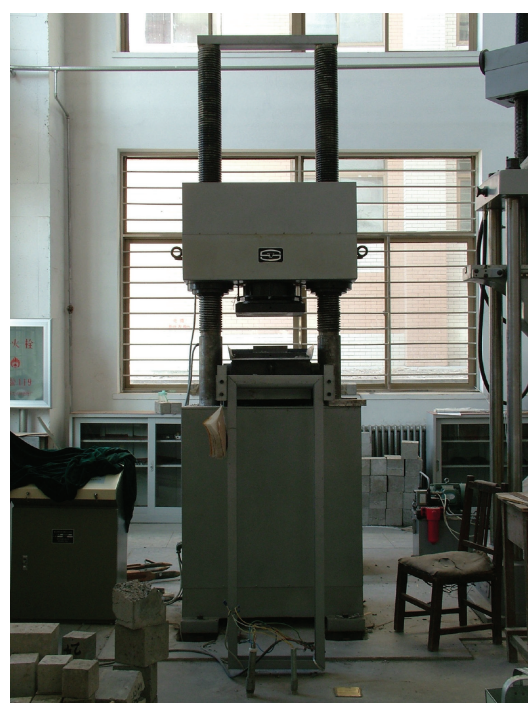

FIGURE 2: Compression testing machine.

The friction between loading plate and loading surface hinders the development of tensile strain close to loading surface. So the cracks will not form or the number of cracks will be reduced near the loading surface. The restriction effect of the friction between loading plate and loading surface on the development of tensile strain at the middle of the specimen is little. So the cracks near the middle of specimen will form. And the taper-type fragments were observed for HPC under uniaxial compression without friction-reducing pads.

The splitting tensile strain along the unload plane(s) was the cause of failure for both. It was obvious that the influence of elevated temperature on HPC did not change the tensile splitting mode from occurring. There was no great change in the failure modes for HPC after the action of elevated temperature.
TABLE 2: The cubic compressive strength of HPC at different ages (MPa).

\begin{tabular}{lcccccccc}
\hline Time $(\mathrm{d})$ & 3 & 7 & 14 & 21 & 28 & 60 & 90 & 120 \\
\hline C50 & 43.00 & 49.93 & 57.01 & 61.20 & 62.71 & 65.75 & 66.83 & 68.17 \\
C60 & 46.73 & 54.27 & 61.97 & 66.52 & 68.17 & 71.47 & 72.64 & 74.10 \\
\hline
\end{tabular}

TABLE 3: The compressive strength and cubic compressive strength of HPC at elevated temperature (MPa).

\begin{tabular}{lcccccc}
\hline \multirow{2}{*}{ Concrete } & & \multicolumn{5}{c}{ Temperature $\left({ }^{\circ} \mathrm{C}\right)$} \\
& & 20 & 200 & 300 & 400 & 500 \\
\hline \multirow{2}{*}{ C50 } & $f_{c}$ & 33.93 & 33.6 & 36.0 .7 & 29.33 & 26.53 \\
& $f_{\mathrm{cu}}$ & 55.16 & 54.40 & 54.67 & 52.00 & 44.37 \\
\hline \multirow{2}{*}{ C60 } & $f_{c}$ & 51.60 & 50.33 & 42.0 & 44.73 & 37.13 \\
& $f_{\mathrm{cu}}$ & 68.17 & 66.62 & 63.51 & 67.0 & 55.53 \\
\hline
\end{tabular}

\subsection{Strength}

3.2.1. The Cubic Compressive Strength and Compressive Strength. The compressive stress was calculated by dividing the compressive load by the area of loading section $\left(0.01 \mathrm{~m}^{2}\right)$. For each mixture, a minimum of three specimens were tested at $3,7,14,21,28,60,90$, and 120 days. Tables 2 and 3 provide the basic physical properties cubic compressive strength and compressive strength for the high-performance concrete at different ages, respectively.

The C50 and C60 concrete developed a 3-day compressive strength of 43.0 MPa and 46.73 MPa, respectively. (These high values are mainly due to the high fineness of the cement used. However, the 3-day compressive strength of the concrete made with the fly ash is still adequate for most of the concrete structures for formwork removal at three days.) At 7 days, the compressive strength of the C50 concrete approached that of the control concrete $(50 \mathrm{MPa})$, and at 14 days it $(57.01 \mathrm{MPa})$ surpassed design value of strength $(50 \mathrm{MPa})$. While for C60 concrete, the compressive strength surpassed design value of strength $(60 \mathrm{MPa})$ at 21 days. In fact, the 28 -day compressive strength of the C50 and C60 concrete was 22\% and 11\% higher than the design value of strength, respectively.

The variation of the cubic compressive strength and compressive strength with time for two types of highperformance concrete is shown in Figure 4.

The variation of the cubic compressive strength and compressive strength with temperature is given in Table 3 for two types of high-performance concrete. In two types of HPC, temperature has a slight bearing on the cubic compressive strength of concrete in the temperature range from $20^{\circ} \mathrm{C}$ to $300^{\circ} \mathrm{C}$. Initially, as the temperature increased to $200^{\circ} \mathrm{C}$, the strength decreased compared to the original strength. With further increase in temperature, the specimens recovered part of their strength at $300^{\circ} \mathrm{C}$. The strength at $300^{\circ} \mathrm{C}$ is about $99.1 \%$ and $93.2 \%$ of the original strength (at $20^{\circ} \mathrm{C}$ ) for $\mathrm{C} 50$ and $\mathrm{C} 60$, respectively. During the temperature range of $400^{\circ} \mathrm{C}$ to $500^{\circ} \mathrm{C}$, the strength drops sharply, reaching a low level of $80.4 \%$ and $81.5 \%$ of initial strength for C50 and C60, respectively. The cubic compressive strength of HPC with temperature is shown in Figure 5. 


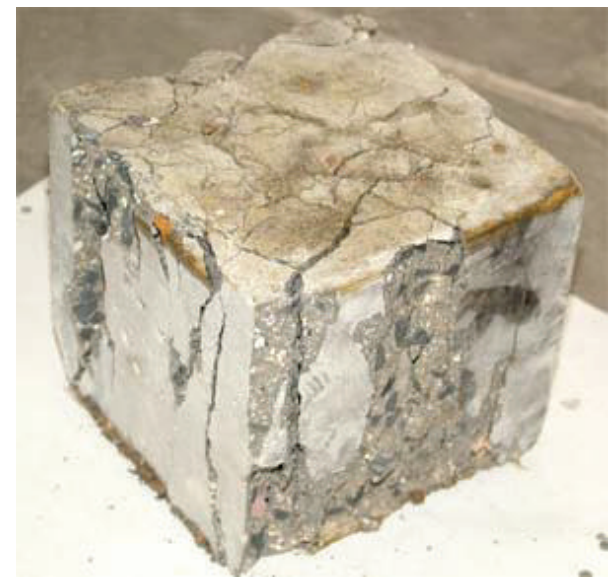

(a)

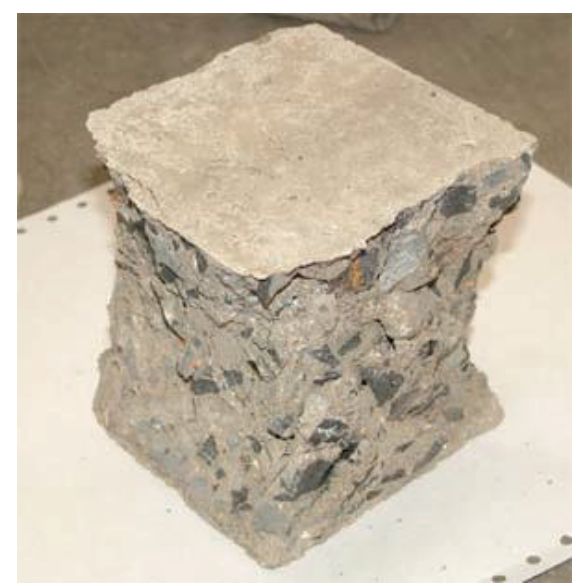

(b)

FIGURE 3: Failure modes of HPC under uniaxial compression.

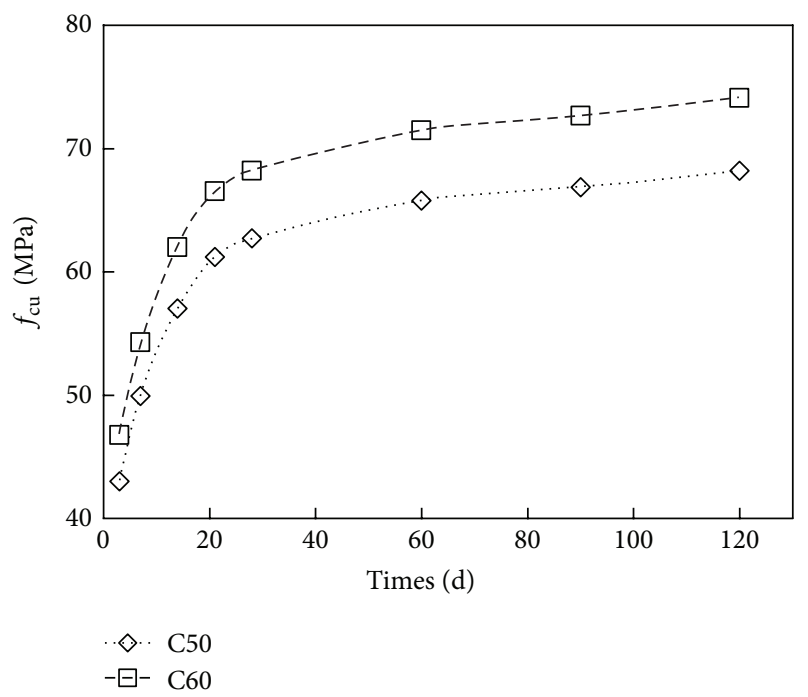

FIGURE 4: The variation of the cubic compressive strength with time.

In the temperature range of $20^{\circ} \mathrm{C}$ to $200^{\circ} \mathrm{C}$, the change of compressive strength is slight. Initially, as the temperature increased to $200^{\circ} \mathrm{C}$, the strength decreased by $1.0 \%$ and $2.5 \%$ percent of the original strength. In the temperature range of $200^{\circ} \mathrm{C}$ to $300^{\circ} \mathrm{C}$, the compressive strength of C50 increases to 1.06 times the original strength, while the compressive strength of C60 drops to $81.4 \%$ of the original strength. In the temperature range of $400^{\circ} \mathrm{C}$ to $500^{\circ} \mathrm{C}$, all two types of HPC lose their strength at a faster rate, and the strength drops sharply, reaching a low level of $78.2 \%$ and $72.0 \%$ of initial strength for $\mathrm{C} 50$ and $\mathrm{C} 60$, respectively. At these temperatures, the dehydration of the cement paste results in its gradual disintegration. Since the paste tends to shrink and aggregate expands at high temperature (differential thermal expansion at temperatures above $100^{\circ} \mathrm{C}$ ), the bond between the aggregate and the paste is weakened, thus reducing the strength of the concrete. Figure 6 gives the change of

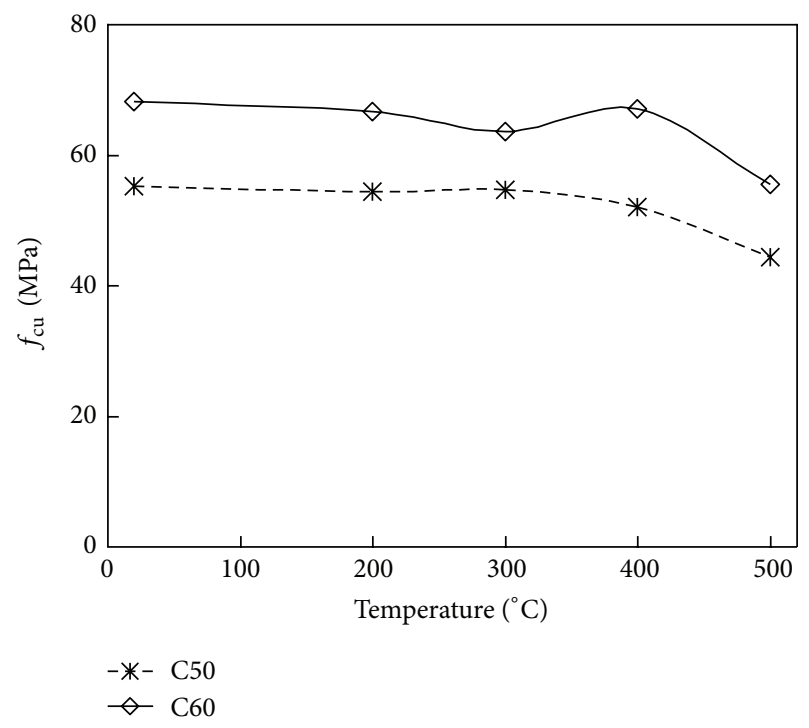

FIGURE 5: Cubic compressive strength of HPC at elevated temperature.

compressive strength of HPC with temperature. This was different from the result in [19]. The test results in [19] indicated that each temperature range had a distinct pattern of strength loss.

3.2.2. The Cleavage Strength and Flexural Strength. Cleavage strength and flexural strength of the concrete are given in Tables 4 and 5. The loading mode of cleavage test meeting (Testing Code of Concrete for Port and Waterwog Engineering) [20] was used. The 120-day cleavage strengths were 3.80 and $4.47 \mathrm{MPa}$ for C50 and C60, respectively. The 120-day flexural strengths were 7.80 and $8.38 \mathrm{MPa}$ for C50 and C60, respectively.

In the temperature range of $20^{\circ} \mathrm{C}$ to $200^{\circ} \mathrm{C}$, temperature has a slight bearing on the cleavage compressive strength of two types of HPC concrete. The cleavage strength at $300^{\circ} \mathrm{C}$ 


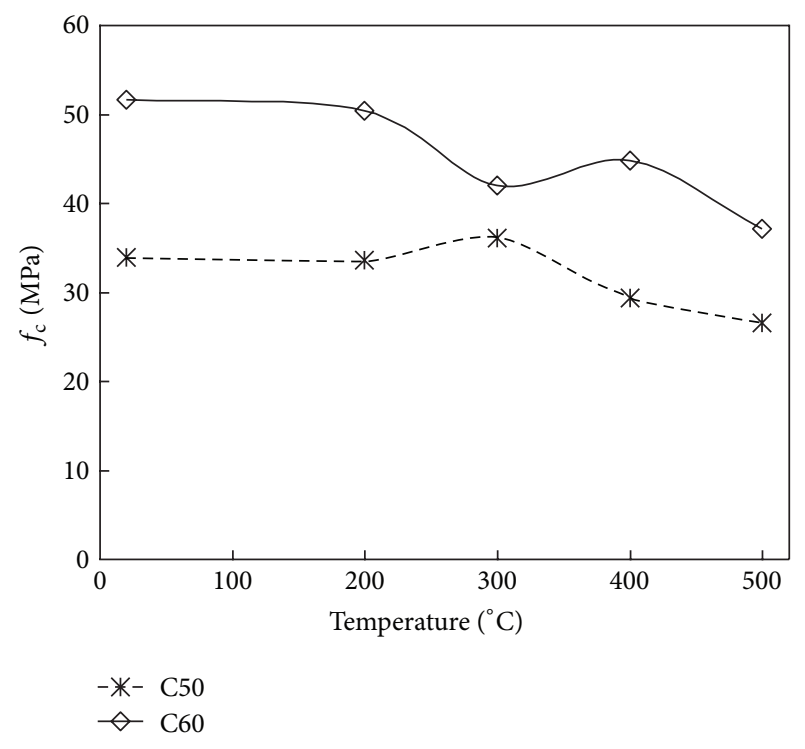

FIGURE 6: Compressive strength of HPC at elevated temperature.

TABLE 4: The cleavage strength of HPC at elevated temperature (MPa).

\begin{tabular}{lccccc}
\hline \multirow{2}{*}{ Concrete } & \multicolumn{5}{c}{ Temperature $\left({ }^{\circ} \mathrm{C}\right)$} \\
& 20 & 200 & 300 & 400 & 500 \\
\hline C50 & 3.800 & 3.756 & 3.790 & 2.984 & 2.362 \\
C60 & 4.474 & 4.401 & 4.098 & 3.310 & 2.916 \\
\hline
\end{tabular}

TABLE 5: The flexural strength of HPC at elevated temperature $(\mathrm{MPa})$.

\begin{tabular}{lccccc}
\hline \multirow{2}{*}{ Concrete } & \multicolumn{5}{c}{ Temperature $\left({ }^{\circ} \mathrm{C}\right)$} \\
& 20 & 200 & 300 & 400 & 500 \\
\hline C50 & 7.800 & 6.961 & 5.404 & 4.644 & 4.290 \\
C60 & 8.380 & 8.253 & 6.565 & 5.834 & 5.378 \\
\hline
\end{tabular}

of C50 and C60 is about $99.7 \%$ and $91.6 \%$ of the original strength $\left(\right.$ at $\left.20^{\circ} \mathrm{C}\right)$, respectively. Above $300^{\circ} \mathrm{C}$, the two types of HSC lose their cleavage strength at a faster rate. The cleavage strength at $500^{\circ} \mathrm{C}$ of $\mathrm{C} 50$ and $\mathrm{C} 60$ is about $62.2 \%$ and $65.2 \%$ of the original strength $\left(\right.$ at $20^{\circ} \mathrm{C}$ ), respectively. The variation of the cleavage strength with temperature is shown in Figure 7.

Flexural strength is the most commonly used procedure to evaluate the toughness, and three-point bending tests are also carried out. For each mixture, the flexural strength was determined on two prisms each at elevated temperature (20, $200,300,400$, and 500). In the temperature range of $20^{\circ} \mathrm{C}$ to $200^{\circ} \mathrm{C}$, the change of fleural strength is slight. Initially, as the temperature increased to $200^{\circ} \mathrm{C}$, the strength decreased $10.8 \%$ and $1.5 \%$ of the original strength for C50 and C60, respectively. As the temperature increased from $200^{\circ} \mathrm{C}$ to $500^{\circ} \mathrm{C}$, the flexural strength dropped sharply compared to the original strength. Overall, HPC at elevated temperatures loses a significant amount of its compressive strength above $200^{\circ} \mathrm{C}$ and attains a strength loss of about $45.0 \%$ and $35.8 \%$

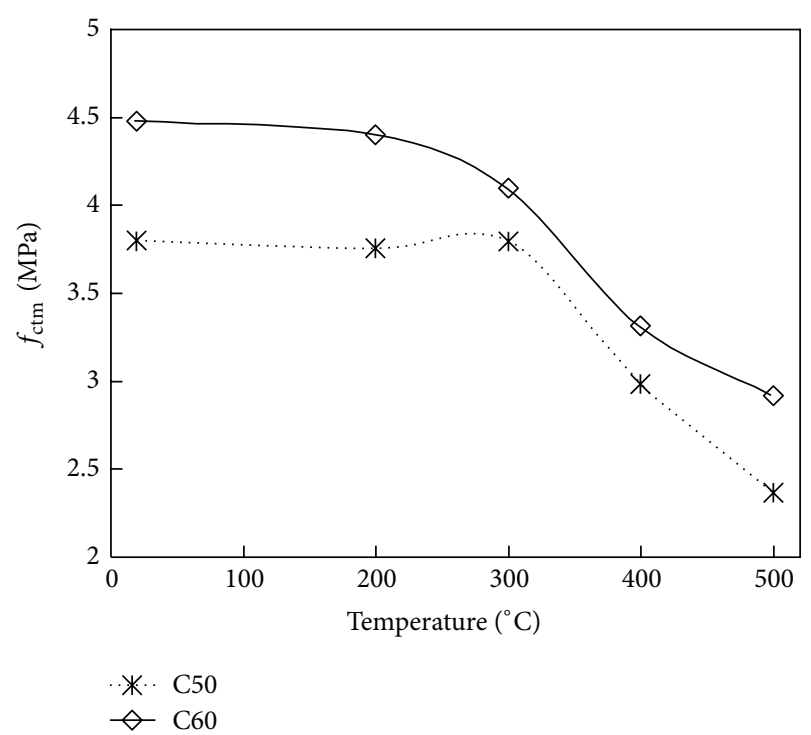

FIGURE 7: Cleavage strength of HPC at elevated temperature.

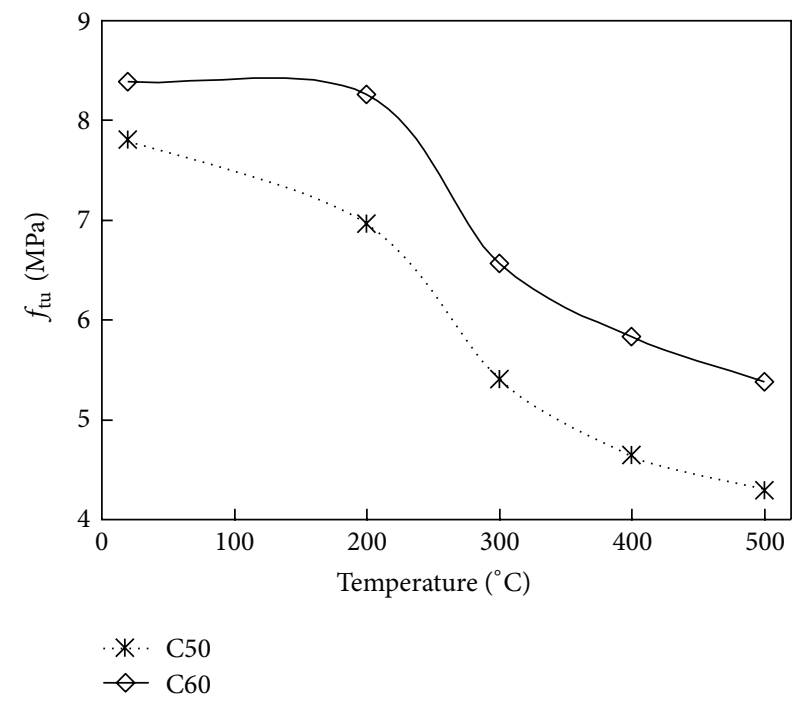

FIgURE 8: Flexural strength of HPCat elevated temperature.

at $500^{\circ} \mathrm{C}$ for $\mathrm{C} 50$ and $\mathrm{C} 60$, respectively. Figure 8 shows the flexural strength of HPC with elevated temperature.

3.3. The Ultrasonic Velocity. A lot of structures, like bridges, tunnels, dams, buildings, and others, were constructed with concrete material. During the life cycle of these structures, degradations can occur under mechanical, thermal, or chemical stresses. These often lead to the development of porosity, microcracks, and cracks in the material. Knowing the concrete structure state to prevent or repair damage is needed and so the nondestructive characteristic is an important stake, the ultrasonic method is often proposed. Ultrasound (sonic (frequency: from 20 to $20,000 \mathrm{~Hz}$ ) human hearing range, subsonic (frequency: $<20 \mathrm{~Hz}$ ), and ultrasonic (frequency: $>20,000 \mathrm{~Hz}$ )) is sound above the human hearing 
TABLE 6: Loss of the ultrasonic velocity of HPC at elevated temperature.

\begin{tabular}{lccccc}
\hline \multirow{2}{*}{ Concrete } & \multicolumn{5}{c}{ Temperature $\left({ }^{\circ} \mathrm{C}\right)$} \\
& 200 & 300 & 400 & 500 & 500 \\
\hline C50 & 100 & 85.9 & 81.8 & 76.1 & 61.2 \\
C60 & 100 & 92.2 & 80.8 & 69.3 & 58.5 \\
\hline
\end{tabular}

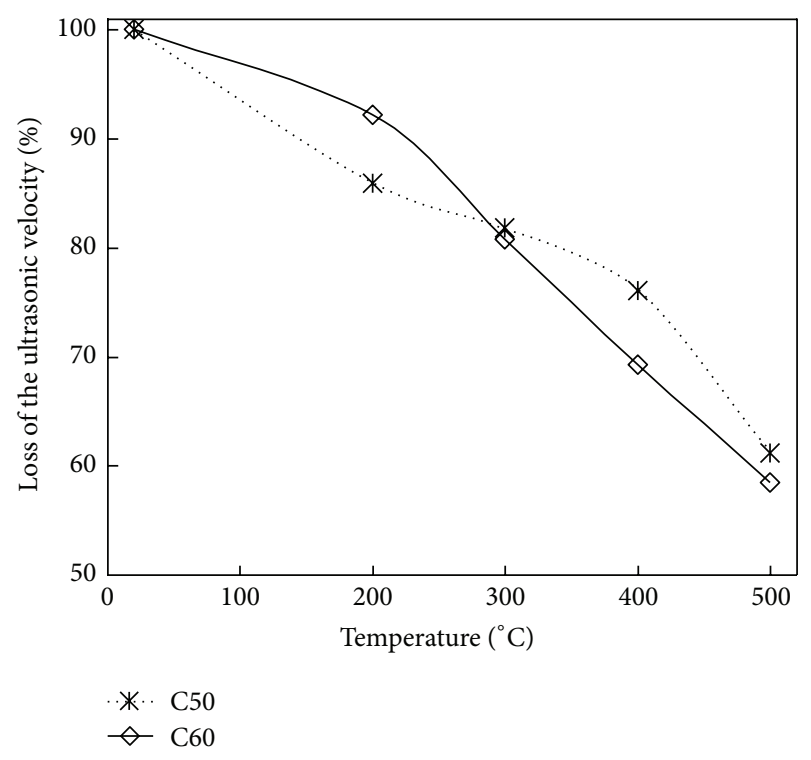

FIGURE 9: Loss of the ultrasonic velocity at elevated temperature.

range. Ultrasonic velocity is the speed in which sound travels through a given material. It is affected by density and elasticity. Velocity remains constant in a given material.

Table 6 gives the decreasing percentage of the ultrasonic velocity with temperature for high-performance concrete. As seen from Table 6 the ultrasonic velocity decreased as temperature. The ultrasonic velocity at $500^{\circ} \mathrm{C}$ of $\mathrm{C} 50$ and C60 is about $61.2 \%$ and $58.5 \%$ of the original velocity (at $20^{\circ} \mathrm{C}$ ), respectively. Loss of the ultrasonic velocity of HPC with elevated temperature is shown in Figure 9.

3.4. The Surface Characteristics and Spalling. The induction of color change in concrete is associated with maximum temperature of exposure and loss in mechanical properties. By combining the changes of strength, color, and temperature during fire, the retained strength of concrete can be inferred primarily. This will provide some reference for concrete structure in practice. It can be said that, in the buildings damaged by fire, by examining the color of concrete surface, we can have some ideas about the change in the concrete strength [21]. So the change of color was observed; according to the visual inspection, a variation with color is revealed, and for concrete subject to $300^{\circ} \mathrm{C}$, color does not change and it is gray, off-white when the concrete is exposed to temperature of between $400^{\circ} \mathrm{C}$ and $600^{\circ} \mathrm{C}$.

Tanyildizi and Coskun [19] investigated the surface cracks; the results are as follows: the surface cracks started to appear at round $400^{\circ} \mathrm{C}$, and continued to grow till the final rise in temperature up to $800^{\circ} \mathrm{C}$. The crack decreased with the increase of fly ash content and at the same time increased with the increase of temperature. And no surface cracks were observed in the experiment.

However spalling has been identified as a problem with HPC by other researchers [22, 23]. But no evidence of spalling was founded during the simulated fire tests for HPC.

\section{Conclusion}

Based on the experimental work in this study and the discussion about test results, the following conclusions can be drawn

(1) The thermal properties, at elevated temperatures, exhibited by high-performance concrete are similar to those of plain concrete.

(2) The failure modes of HPC under uniaxial compression with and without friction-reducing pads were column-type fragments and taper-type fragments, respectively. The splitting tensile strain along the unload plane(s) was the cause of failure for both.

(3) Above $300^{\circ} \mathrm{C}$, the two types of HSC lose their cleavage strength at a faster rate. The cleavage strength at $500^{\circ} \mathrm{C}$ of $\mathrm{C} 50$ and $\mathrm{C} 60$ is about $62.2 \%$ and $65.2 \%$ of the original strength $\left(\right.$ at $\left.20^{\circ} \mathrm{C}\right)$, respectively. As the temperature increased from $200^{\circ} \mathrm{C}$ to $500^{\circ} \mathrm{C}$, the flexural strength dropped sharply compared to the original strength.

(4) The present study was undertaken to establish the thermal properties of HPC at elevated temperatures. The data can be used to develop mathematical models to predict the fire resistance of HPC structural members.

\section{Acknowledgments}

This research work was jointly supported by the Science Fund for Creative Research Groups of the National Natural Science Foundation of China (Grant no. 51121005), the National Natural Science Foundation of China (Grant no. 51208273 and 51222806), a Project of Shandong Province Higher Educational Science and Technology Program (Grant no. J12LG07), and the Program for New Century Excellent Talents in University (Grant no. NCET-10-0287).

\section{References}

[1] S. Y. N. Chan, X. Luo, and W. Sun, "Effect of high temperature and cooling regimes on the compressive strength and pore properties of high performance concrete," Construction and Building Materials, vol. 14, no. 5, pp. 261-266, 2000.

[2] A. Neville and P. C. Aitcin, "High performance concrete-an overview," Materials Structure, vol. 31, pp. 111-117, 1998.

[3] M. Nehdi, S. Mindess, and P. C. Aïtcin, "Rheology of highperformance concrete: effect of ultrafine particles," Cement and Concrete Research, vol. 28, no. 5, pp. 687-697, 1998. 
[4] Y. N. Chan, G. F. Peng, and M. Anson, "Spalling mechanism and fire resistance of high performance silica fume concrete with different moisture content," in Proceedings of the 4th Beijing International Symposium on Cement and Concrete, vol. 3, pp. 149-153, Beijing, China, 1998.

[5] J. Z. Xiao, P. Wang, J. Li, and S. D. Zhang, "Test on compressive strength of HPC with blast furnace slag after high temperature," in Proceedings of the Fourth National Conference on HSC and HPC, pp. 204-210, Changsha, China, 2001.

[6] R. Demirboǧa, I. Örüng, and R. Gül, "Effects of expanded perlite aggregate and mineral admixtures on the compressive strength of low-density concretes," Cement and Concrete Research, vol. 31, no. 11, pp. 1627-1632, 2001.

[7] A. Bilodeau and V. M. Malhotra, "High-volume fly ash system: concrete solution for sustainable development," ACI Structural Journal, vol. 97, no. 1, pp. 41-48, 2000.

[8] A. Yeğinobalı, K. G. Sobolev, S. V. Soboleva, and B. Kıyıcı, "Thermal resistance of blast furnace slag high strength concrete cement," in Proceedings of the 1st International Symposium on Mineral Admixtures in Cement, pp. 106-117, Istanbul, Turkey, 1997.

[9] G. Y. Kim, Y. S. Kim, and T. G. Lee, "Mechanical properties of high-strength concrete subjected to high temperature by stressed test," Transactions of Nonferrous Metals Society of China, vol. 19, no. 1, pp. s128-s133, 2009.

[10] C. S. Poon, Z. H. Shui, and L. Lam, "Compressive behavior of fiber reinforced high-performance concrete subjected to elevated temperatures," Cement and Concrete Research, vol. 34, no. 12, pp. 2215-2222, 2004.

[11] W. Khaliq and V. Kodur, "Thermal and mechanical properties of fiber reinforced high performance self-consolidating concrete at elevated temperatures," Cement and Concrete Research, vol. 41, pp. 1112-1122, 2011.

[12] C. Castillo and A. J. Durrani, "Effect of transient high temperture on high-strength concrete," ACI Materials Journal, vol. 87, no. 1, pp. 47-53, 1990.

[13] G. Sanjayan and L. J. Stocks, "Spalling of high-strength silica fume concrete in fire," ACI Materials Journal, vol. 90, no. 2, pp. 170-173, 1993.

[14] C. Castillo and A. J. Durrani, "Effect of transient high temperature on high-strength concrete," ACI Materials Journal, vol. 871, pp. 47-53, 1990.

[15] J. Xiao and H. Falkner, "On residual strength of highperformance concrete with and without polypropylene fibres at elevated temperatures," Fire Safety Journal, vol. 41, no. 2, pp. 115$122,2006$.

[16] GB/T 50081-2002 and National Standard of the People's Republic of China, Standard for Test Method of Mechanical Properties on Ordinary Concrete, 2003.

[17] GB175-99 and National Standard of the People's Republic of China, Portland Cement and Ordinary Portland Cement, 1999.

[18] P. Y. Lu, Y. P. Song, and Z. M. Wu, "Strength and deformation characteristics of concrete subjected to different loading rates combined with confined stress," Journal of Dalian University of Technology, vol. 41, no. 6, pp. 716-720, 2001 (Chinese).

[19] H. Tanyildizi and A. Coskun, "The effect of high temperature on compressive strength and splitting tensile strength of structural lightweight concrete containing fly ash," Construction and Building Materials, vol. 22, no. 11, pp. 2269-2275, 2008.

[20] JTJ 270-98 and National Standard of the People's Republic of China, Testing Code of Concrete for Port and Waterwog Engineering, 1999.
[21] N. Yüzer, F. Aköz, and L. D. Öztürk, "Compressive strengthcolor change relation in mortars at high temperature," Cement and Concrete Research, vol. 34, no. 10, pp. 1803-1807, 2004.

[22] K. D. Hertz, "Danish investigations on silica fume concretes at elevated temperatures," ACI Materials Journal, vol. 89, no. 4, pp. 345-347, 1992.

[23] Y. N. Chan, G. F. Peng, and M. Anson, "Residual strength and pore structure of high-strength concrete and normal strength concrete after exposure to high temperatures," Cement and Concrete Composites, vol. 21, no. 1, pp. 23-27, 1999. 

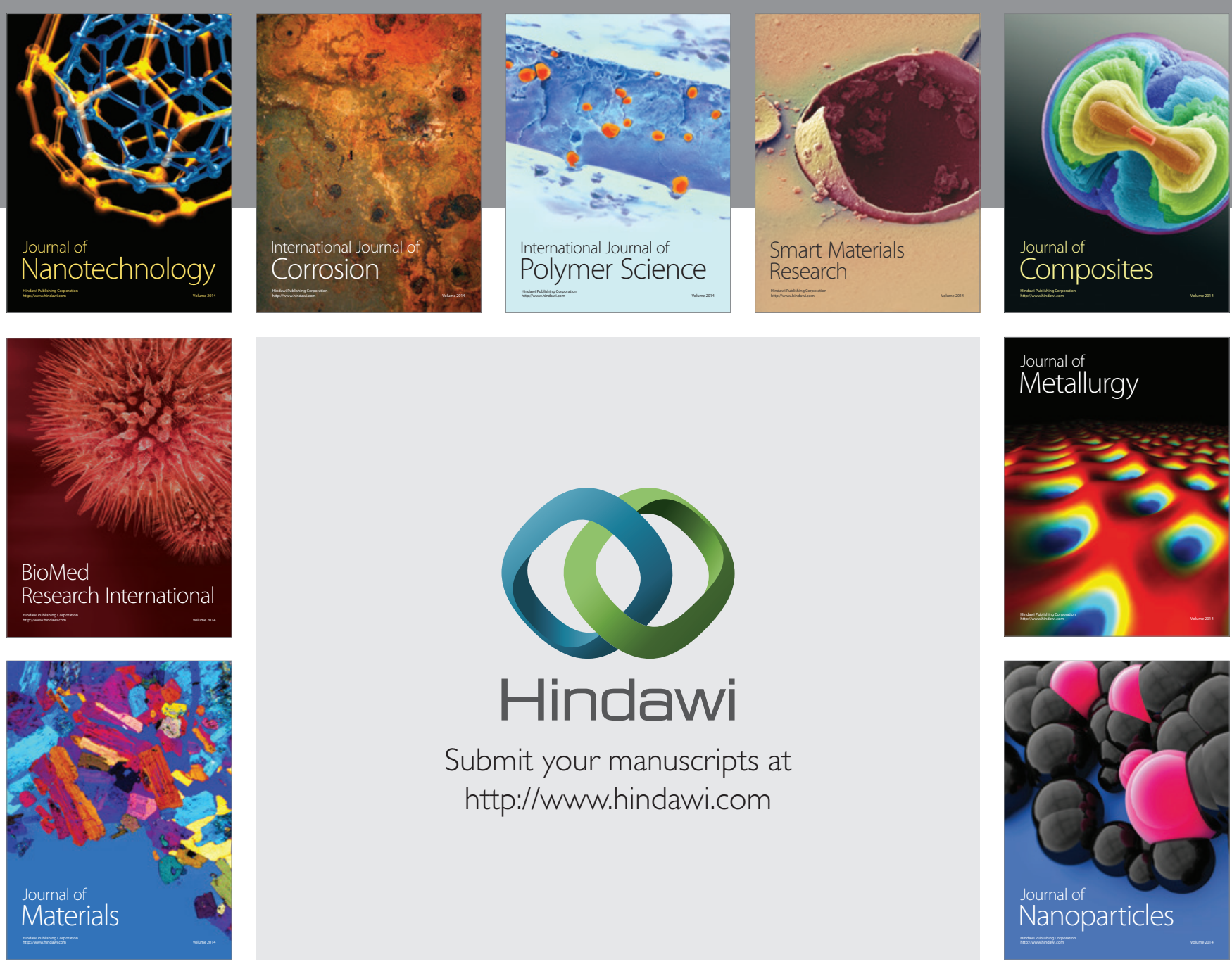

Submit your manuscripts at http://www.hindawi.com
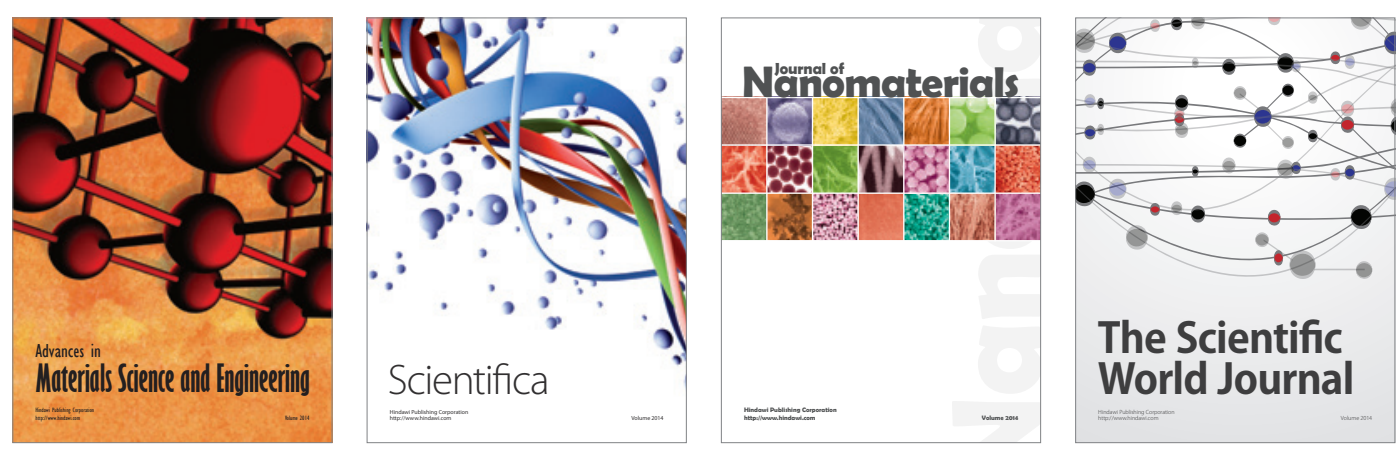

\section{The Scientific World Journal}
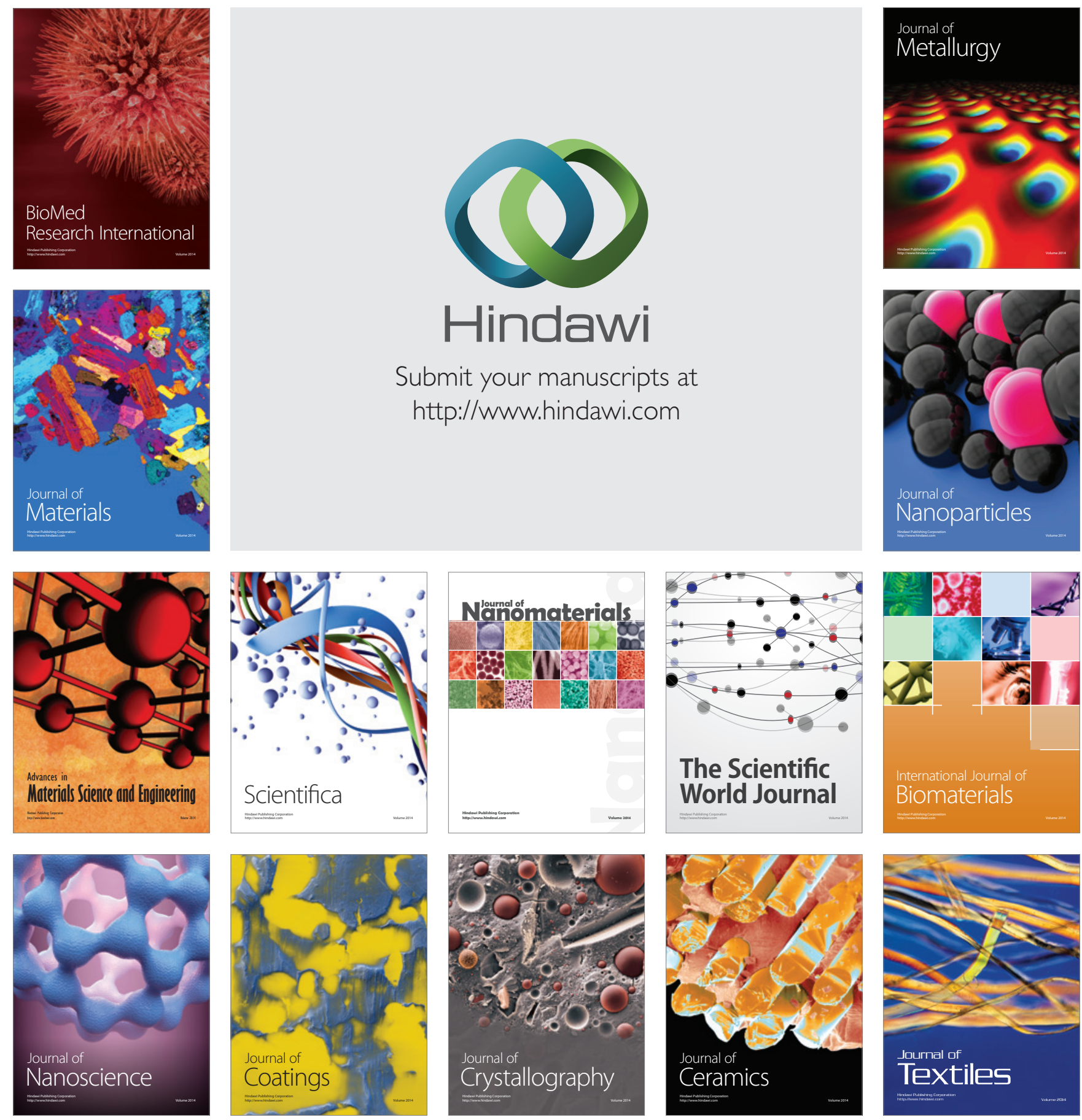